\title{
Combination of cisplatin, Hedyotis corymbosa L. and Tinospora crispa extracts as a new therapy for breast cancer cells 4T1 through in vitro induction and cell cycle modulation
}

\author{
Rollando Rollando*, Muhammad Hilmi Afthoni \\ Department of Pharmacy, Faculty of Science and Technology, Ma Chung University, Malang \\ Jl. Villa Puncak Tidar No.1, Doro, Karangwidoro, Kec. Dau, Malang, East Java, Indonesia
}

\begin{abstract}
Cisplatin is a chemotherapeutic agent with varying side effects. Berberine compounds in Tinospora crispa and ursolic acids in Hedyotis corymbosa L are known to have high cytotoxic activities. This study was aimed to examine the effects of the combination of cisplatin, the ethanolic extract of Hedyotis corymbosa L.(EEHC), and the ethanolic extract of Tinospora crispa roots (EETC) on enhanced breast cancer cell sensitivity by apoptotic induction and cell cycle modulation. Cytotoxic effects were tested using the MTT assay in breast cancer cells, 4T1. The combination test of cisplatin and the extracts yielded combination index (CI) and cell viability, and its effects on the induction of apoptosis and cell cycle modulation were observed by the flow cytometry method. The results of the cytotoxic test showed CI of less than one for $1 \mathrm{mg} / \mathrm{mL}$ EEHC, $6 \mathrm{mg} / \mathrm{mL}$ EETC, and $1.68 \mathrm{mg} / \mathrm{mL}$ cisplatin. The EEHC-EETC-cisplatin combination accumulated cells in the S phase (29.98\%) and induced apoptosis in 4T1 cells. It proves that EEHC and EETC can be developed as co-agents with cisplatin to improve the effectiveness of breast cancer chemotherapeutic treatment.
\end{abstract}

Keywords: Cisplatin, cytotoxicity, Hedyotis corymbosa L., Tinospora crispa

*Corresponding author:

Rollando Rollando

Department of Pharmacy, Faculty of Science and Technology, Ma Chung University, Malang

Jl. Villa Puncak Tidar No.1, Doro, Karangwidoro, Kec. Dau, Malang, East Java, Indonesia

Email: ro.llando@machung.ac.id 


\section{INTRODUCTION}

Cancer is one of the leading causes of death in the world. In 2008, it reportedly led to approximately 7.6 million deaths (around 13\% of total mortality), and this figure is expected to increase to 13.1 million in 2030 (WHO, 2013). Breast cancer ranks first in the number of cases of cancer in women worldwide, with the incidence rate of 1,676,633 (IARC, 2012).

Chemotherapy is the widely proposed treatment for cancer. Chemotherapeutic agents generally have low selectivity because they are antiproliferative against cancer cells and healthy cells (Valeriote et al., 2002). Also, several chemotherapeutic agents have a narrow therapeutic index and can lead to multiple drug resistance and adverse side effects (Minami et al., 2010). Chemotherapy drugs that are mostly used in the treatment of breast cancer are cisplatin. Cisplatin, especially in high doses, can cause varying side effects (Florea and Busselberg, 2011), including neurotoxicity, nephrotoxicity (Milosavlievic et al., 2010), and bone marrow suppression. Therefore, research focusing on finding active and selective methods to cure breast cancer becomes necessary.

Cancer cell treatment strategy is not a one-target but multiple-target mechanism, especially for cell proliferation and migration (Kemper et al., 2014). 4T1 is an example of cancer cells in the metastatic phase that show migration and invasion (Kaur et al., 2012).

Indonesia has various resources that can be potentially developed into chemotherapeutic agents against breast cancer, such as Hedyotis corymbosa L. and Tinospora crispa. H. corymbosa contains ursolic acid, which is known to possess antiproliferative and antiangiogenetic activities, preventing the spread of cancer cells to other organs. Also, ursolic acid can inhibit the regulation of proinflammatory cytokines expression by inhibiting the activation of NF- $\mathrm{KB}$ (Foo and Nolan, 1999). Berberine isolated from Tinospora crispa has cytotoxic activity against HCT-8 cells, NUGC Cells, and Hone-1 cells (Damu et al., 2009).

Doses of chemotherapeutic agents can be reduced by combining them with compounds found in natural ingredients as an attempt to minimize adverse side effects while maintaining similar therapeutic properties against target cells (Zhao et al., 2005). Moreover, Zhao et al. (2005) confirm that $H$. corymbosa and $T$. crispa extracts can be potentially developed in combination therapy with cisplatin for breast cancer treatment. This combination is expected to lower the required dose of cisplatin and, consequently, lessen its side effects. This study was conducted to assess the cytotoxic effects of the combination of the ethanolic extract of $H$. corymbosa (EEHC), the ethanolic extract of $T$. crispa (EETC), and cisplatin through cell cycle modulation and apoptosis induction.

\section{MATERIALS AND METHOD \\ Materials}

Materials used in this research were Hedyotis corymbosa L. and Tinospora crispa powder obtained from UPT Materi Materia Medica Batu, Malang.

\section{Methods}

Extraction of $H$. corymbosa roots and $T$. crispa leaves

H. corymbosa weighing 250 grams was macerated with 1 liter of $96 \%$ ethanol for one day. The liquid was then evaporated with a solvent to create a thick consistency (Rollando, 2018). This procedure was also applied to T. crispa.

\section{Identification of chemical compounds in extracts}

Two $\mathrm{mg}$ of both extracts were dissolved in $1 \mathrm{~mL}$ of ethanol. The extracts were spotted on TLC plates and then inserted into a chamber containing chloroform-ethanol 9: 1 as the mobile phase. Once the mobile phase reached the predefined mark, the plates were removed, sprayed with 
Cerium (IV) Sulfate hydrate and Dragendorff's reagent, and dried in an oven. The band formed was then observed to calculate the HRF value.

\section{Cell preparation and harvesting}

The 4T1 cells were transferred to a conical tube containing high-glucose DMEM and centrifuged at $600 \mathrm{rpm}$ for 5 minutes. After the supernatant was discarded, new media was added to the flask, and the cells were suspended until homogeneous. Cell suspensions were grown in Tissue Culture Dish (TCD) and incubated in a $\mathrm{CO}_{2}$ incubator at $37^{\circ} \mathrm{C}$. Cells were observed under a microscope and incubated in a $5 \% \mathrm{CO}_{2}$ incubator. After reaching $\pm 80 \%$ confluence, they were harvested by removing the media. Then, the cells were washed with $3 \mathrm{~mL}$ of PBS 2 times, added with $0.25 \%$ trypsin-EDTA, and incubated for 1 minute in a $\mathrm{CO}_{2}$ incubator.

A total of $3 \mathrm{~mL}$ of the media were added into TCD that contained the cells. Then, the cells were resuspended on the walls and at the bottom of TCD using a micropipette to prevent cell clumping. The cell suspension was transferred to a new sterile conical tube, and it was enumerated using a hemocytometer and cell counter. The cells were then formed into a cell suspension at predefined concentrations. The cytotoxic tests of single and combination solutions were performed at a density of $8 \times 10^{4}$ cells.

A stock solution of each extract was diluted with the culture medium to obtain concentrations of $1,10,25,50,75,100$, and $200 \mathrm{mg} / \mathrm{mL}$. These solutions were used in single cytotoxic tests. Meanwhile, the cisplatin test solution was diluted with the culture medium at concentrations of $0.5,1,2,4$, and $8 \mu \mathrm{g} / \mathrm{mL}$ (Rollando, 2018).

\section{Cytotoxic tests of single and combination treatments using MTT assay}

Cells were harvested, diluted with the culture medium, implanted into a 96-well microplate (with a volume of $100 \mathrm{~mL} / \mathrm{wells}$ ), and incubated for 24 hours in a $5 \% \mathrm{CO}_{2}$ incubator. Before the treatment, the media in the plate was removed and washed with 1x PBS (as many as 100 $\mathrm{mL} /$ pitting). Afterward, the PBS was removed, and the cells were given a test solution of 100 $\mathrm{mL} /$ pitting (Rollando, 2018).

After 24 hours of incubation, the cells were washed with PBS, added with $100 \mathrm{~mL} /$ pitting of MTT reagent, and incubated for $3-4$ hours at $37^{\circ} \mathrm{C}$. The stopper solution $(10 \%$ SDS in $0.01 \mathrm{~N} \mathrm{HCl})$ was added, with a volume of $100 \mathrm{~mL} /$ wells. The cells were incubated overnight in the dark at room temperature and then measured with an ELISA reader at $\lambda 595 \mathrm{~nm}$ to obtain absorption equivalent to the absorbance of living 4T1 cells (Rollando, 2018).

The absorbance data of the single treatment were converted into percent viability, which is a factor in the calculation of $\mathrm{IC}_{50}$. Based on the $\mathrm{IC}_{50}$ value, the cytotoxicity of the EEHC-EETCcisplatin combination at various levels was tested. The results are shown in Table I. 
Table I. Comparison of concentrations in the combination of Hedyotis corymbosa L. Extract, Tinospora crispa Extract, and Cisplatin

\begin{tabular}{|c|c|c|c|}
\hline $\begin{array}{c}\text { Comparison of Treatment } \\
\text { Combinations }\end{array}$ & Single treatment & Single treatment & Single treatment \\
\hline $\begin{array}{l}\operatorname{EEHC~}\left(\mathrm{IC}_{50} 1 / 12\right) ; \\
\operatorname{EETC}\left(1 / 12 \mathrm{IC}_{50}\right) ; \\
\mathrm{C}\left(1 / 12 \mathrm{IC}_{50}\right)\end{array}$ & $\operatorname{EEHC}\left(1 / 12 \mathrm{IC}_{50}\right)$ & $\operatorname{EETC}\left(1 / 12 \mathrm{IC}_{50}\right)$ & $\mathrm{C}\left(1 / 12 \mathrm{IC}_{50}\right)$ \\
\hline $\begin{array}{l}\text { EEHC }\left(1 / 6 \mathrm{IC}_{50}\right) ; \\
\text { EETC }\left(1 / 6 \mathrm{IC}_{50}\right) ; \\
\text { C }\left(1 / 6 \mathrm{IC}_{50}\right)\end{array}$ & $\operatorname{EEHC}\left(1 / 6 \mathrm{IC}_{50}\right)$ & $\operatorname{EETC}\left(1 / 6 \mathrm{IC}_{50}\right)$ & $\mathrm{C}\left(1 / 6 \mathrm{IC}_{50}\right)$ \\
\hline $\begin{array}{l}\operatorname{EEHC}\left(1 / 3 \mathrm{IC}_{50}\right) ; \\
\operatorname{EETC}\left(1 / 3 \mathrm{IC}_{50}\right) ; \\
\text { C }\left(1 / 3 \mathrm{IC}_{50}\right)\end{array}$ & $\operatorname{EEHC}\left(1 / 3 \mathrm{IC}_{50}\right)$ & $\operatorname{EETC}\left(1 / 3 \mathrm{IC}_{50}\right)$ & $\mathrm{C}\left(1 / 3 \mathrm{IC}_{50}\right)$ \\
\hline $\mathrm{KS}$ & $\mathrm{KS}$ & KM & KM \\
\hline
\end{tabular}

\section{Flow cytometry}

Cells $\left(5 \times 10^{5}\right.$ cells/wells) were grown in a 6-well plate, incubated for 24 hours, and treated with EEHC, EETC, cisplatin (WAKO), and their combination. For the cell cycle analysis, trypsinized adherent cells were collected and detected by adding the flow cytometry reagent (PI+RNase+Triton-X) and then incubated for 10 minutes. The apoptotic cells were detected using the FLOUS-Annexin V Apoptosis Detection Kit. The cell suspension was transferred into a flow cytometer tube, and cell cycle profiles were read by FACSCalibur flow cytometer. The Data were analyzed in the Flowing software to determine the distribution of cells in each phase of the cell cycle (Rollando, 2018).

Data Analysis

Analysis of single cytotoxic agents

Data on absorbance were converted to percent viability using the formula below:

$$
\% \text { live cell }=\frac{(\text { Abs observed }- \text { Abs media control })}{(\text { Abs cell control }- \text { Abs media control })}
$$

Cell viability was analyzed in Microsoft Excel 2007 to obtain linearity (r) and $\mathrm{IC}_{50}$ from the curve of concentrations (log values) and the percentage of cell viability. The $r$-value was compared with the table $(\mathrm{p}<0.05)$. The effectiveness of the test compound was determined by the percentage of reduction in cell viability (Rollando, 2018).

\section{Comparative analysis of cell viabilities in the EEHC-EETC-Cisplatin combination treatment}

The cytotoxic effects of the mixture were conducted by MTT assay. The combined effects were identified by calculating the Chou's Combination Index and Drug Reduction Index (DRI) (Reynolds and Maurer, 2005) for EEHC, EETC, and cisplatin in CompuSyn program. 


$$
C l=\frac{(D) 1}{(D x) 1}+\frac{(D) 2}{(D x) 2}+\frac{(D) 3}{(D x) 3}
$$

Description: (Dx) 1, (Dx) 2, and (Dx) 3 denote the concentration of single compounds for combination treatment (x). (D)1, (D)2, and (D)3 denote the concentration of each test compound used to examine the combination.

Table II. Combination index (CI) interpretation (Matthews et al., 2017)

\begin{tabular}{ll}
\hline CI values & Interpretations \\
\hline$<\mathbf{0 . 1}$ & Powerful synergistic effect \\
$\mathbf{0 . 1 - 0 . 3}$ & Strong synergistic effect \\
$\mathbf{0 . 3 - 0 . 7}$ & Synergistic effect \\
$\mathbf{0 . 7 - 0 . 9}$ & Mild-moderate synergistic effect \\
$\mathbf{0 . 9 - 1 . 1}$ & Nearly addictive effect \\
$\mathbf{1 . 1 - 1 . 4 5}$ & Mild-moderate antagonistic effect \\
$\mathbf{1 . 4 5 - 3 . 3}$ & Antagonistic effect \\
$\mathbf{>}$ 3.3 & Strong-very strong antagonistic effect \\
\hline
\end{tabular}

\section{Apoptosis and cell cycle analyses}

The data on flow cytometry show the percentage of cells in four quadrants, namely LL (lower left, representing the percentage of live cells), LR (lower right, the percentage of early apoptotic cells), UL (upper left, the percentage of necrotic cells), and UR (upper right, the percentage of late apoptotic cells). These data were analyzed to identify the distribution of cells in each phase of the cell cycle (i.e., G1, S, and G2/M). The inhibition of the cell cycle can be detected by comparing the therapeutic effects of the test solution on control cells.

\section{RESULTS AND DISCUSSION}

\section{Chemical compounds of the test extracts}

The chemical examination was carried out to confirm that EETC and EEHC contain alkaloids and terpenoids, which have been scientifically proven to exhibit cytotoxic activity (Lin et al., 2002). The results of the identification test using Cerium (IV) Sulfate hydrate as the reagent showed that the EETC had an HRF of 5, while EEHC had HRF values of 16 and 25 (Figure 1).

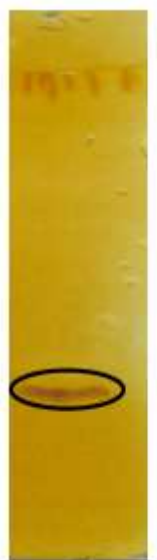

a

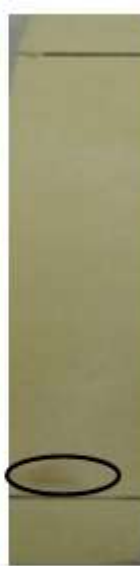

b

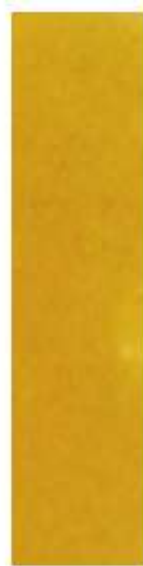

C

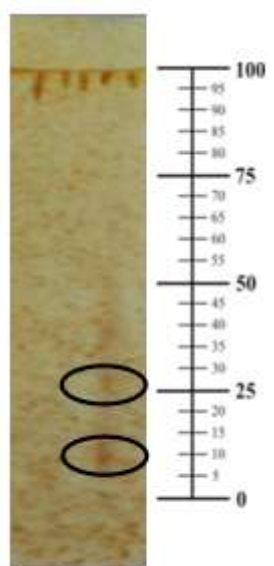

d

Figure 1. Test results with the Dragendorff's reagent for (a) EEHC and (c) EETC. Test results with Cerium (IV) Sulfate for (b) EETC and (d) EEHC. Elution was carried out with silica gel $60 \mathrm{~F} 254$ as the stationary phase and the mixture of chloroform: methanol (9: 1) as the mobile phase. The detection was carried out using visible light 
The above results indicate that the plant extracts are both carbon atoms (Harborne, 1987). When the EETC plate was sprayed with the Dragendorff's reagent, a reddish-orange stain with an HRF of 25 appeared. On the contrary, there was no stain formed on the EEHC plate. In this case, orange-brown stains represent a positive reaction for alkaloids (MOH, 1985). Accordingly, EETC contains alkaloids, whereas EEHC does not. Other compounds found in both extracts are one type of triterpenoid in EETC (Aprianto et al., 2017) and two triterpenoids in EEHC, namely, cycloeucalenol and cycloeucalenone (Waqas et al., 2016).

\section{Single cytotoxic activity test results of EEHC, EETC, and cisplatin against 4T1 Cells}

Cytotoxic tests were designed to determine the potential of EEHC, EETC, and cisplatin in inhibiting breast cancer cells, 4T1. The parameter observed was $\mathrm{IC}_{50}$, i.e., the concentration at which a substance triggers the cellular death of $50 \%$ of the population.

Table III. IC $_{50}$ values of EEHC, EETC, and cisplatin in 4T1 Cells

\begin{tabular}{cc}
\hline Samples & IC $_{\mathbf{5 0}}$ \\
\hline EEHC & $5.98 \pm 1.26 \mathrm{mg} / \mathrm{mL}$ \\
EETC & $14.35 \pm 0.54 \mathrm{pg} / \mathrm{mL}$ \\
Cisplatin & $5.04 \pm 0.75 \mathrm{mg} / \mathrm{mL}$ \\
\hline
\end{tabular}

Treatments with EEHC (Figure 2b), EETC (Figure 2c), and cisplatin (Figure 2d) showed a more significant decrease in the live-cell population compared to controls (Figure 2a). The cell size shrank due to due to the loss of cytoplasmic fluid-i.e., the result of membrane disruption, as shown by the detached cell after the above treatments (Florea and Busselberg, 2011).

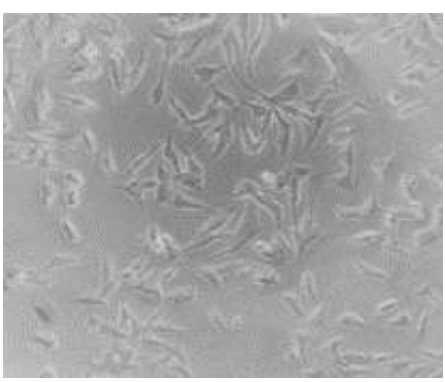

A

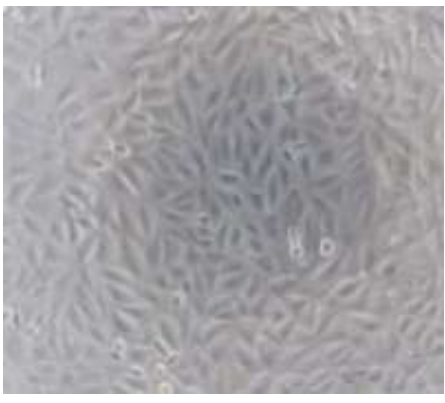

C

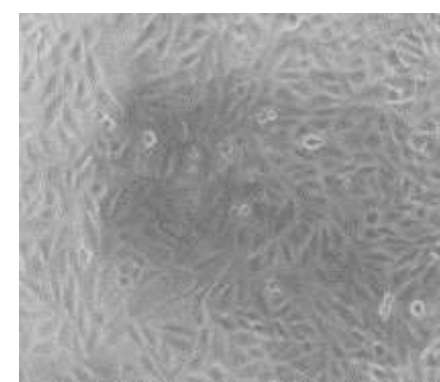

B

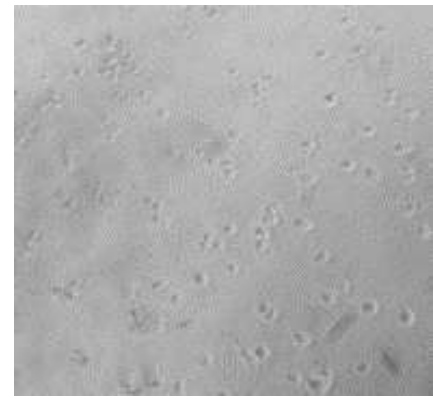

$\mathrm{D}$

Figure 2. The Effects of Various Treatments on 4T1 Cells. A total of 8000 cells/wells in 96well plates after 24 hours of incubation in high-glucose DMEM media. Observations were carried out under an inverted microscope with 100x magnification. (A) Control cells; (B) $5.98 \mathrm{pg} / \mathrm{mL}$ EEHC; (C) $14.35 \mathrm{ug} / \mathrm{mL}$ EETC, (D) $5.04 \mathrm{ug} / \mathrm{mL}$ Cisplatin 


\section{Cytotoxic activity test results of the EEHC-EETC-cisplatin combination against 4T1 Cells}

This study used a series of concentrations for each test substance, namely, $0.5,1$, and 2 $\mathrm{mg} / \mathrm{mL}$ EEHC, $2.5,5$, and $10 \mathrm{mg} / \mathrm{mL}$ EETC, and $1.25,2.5$, and $5 \mu \mathrm{L}$ cisplatin. The combination of EEHC, EETC, and cisplatin required to produce the given effects (i.e., 1/12, 1/6, and 1/3 $\mathrm{IC}_{50}$ ) produced $\mathrm{CI}$ of $<1$ (Table 4 ). In other terms, this combination has a synergistic effect.

Table IV. The combination index (CI) values of cisplatin-EETC-EEHC for 4T1 cells

\begin{tabular}{ccc}
\hline $\begin{array}{c}\text { Concentration } \\
\text { ratio }\end{array}$ & $\begin{array}{c}\text { Cell viability } \\
(\boldsymbol{\%})\end{array}$ & CI \\
\hline $\mathbf{1 / 1 2} \mathbf{I C}_{\mathbf{5 0}}$ & 52.86 & 0.43 \\
$\mathbf{1 / 6} \mathbf{I C}_{\mathbf{5 0}}$ & 45.76 & 0.58 \\
$\mathbf{1 / 3} \mathbf{I C}_{\mathbf{5 0}}$ & 39.87 & 0.86 \\
\hline
\end{tabular}

\section{Modulation of 4T1 cell cycle in the EEHC-EETC-cisplatin combination treatment}

DNA synthesis in cancer cells through the cell cycle is similar to that of healthy cells (Foster, 2008). One of the main targets in inhibiting the proliferation of cancer cells in the modulation of the cell cycle is observable by flow cytometry (King, 2000). Flow cytometry can detect each phase of the cell cycle based on the number of chromosomes in each phase (i.e., $G_{1}, S$, and $G_{2} / M$ ) (Foster, 2008). Propidium iodide was used to color the cells in each phase (Ross et al., 2003). The cell cycle profile was observed at the 24th hour (King, 2000). The percentage distribution of the cell cycle is presented in detail in Table V.

Table V. The Distribution of Cell Cycle (in percent)

\begin{tabular}{lcccc}
\hline Samples & G1 $(\%)$ & S $(\%)$ & G2 / M (\%) & $\%$ CV \\
\hline Control & 48.98 & 11.62 & 24.68 & 8.87 \\
A (1 ug/ml EEHC) & 42.82 & 17.92 & 16.83 & 9.81 \\
B (6 ug/ml EETC) & 34.83 & 13.82 & 24.83 & 8.98 \\
C (1.68 $\mu$ M Cisplatin) & 43.87 & 11.24 & 29.93 & 9.81 \\
The combination of A, B, and C & 24.82 & 29.98 & 15.98 & 7.87 \\
\hline
\end{tabular}

The test results showed that single treatments with EEHC, as well as cisplatin, caused accumulation in $S$ phase, whereas EETC caused accumulation in $S$ and $\mathrm{G}_{2} / \mathrm{M}$ phases. Meanwhile, when compared to the control cells, the combination of EEHC, EETC, and cisplatin caused a collection of cells in the $S$ phase. In the combination treatment, the percentage distribution of the $S$ phase was $29.98 \%$ or higher than single treatments with cisplatin, which amounted to $11.24 \%$. The combination treatment result increased on the S phase $(29.98 \%)$, and the cells accumulate in $\mathrm{S}$ phase due to cell cycle arrest in this phase.

\section{Observation of apoptosis in the EEHC-EETC-cisplatin combination treatment}

Induced apoptosis was used to understand the mechanism of 4T1 cell death caused by EEHC, EETC, cisplatin, and their combinations after 24 hours of incubation. Apoptosis was observed from the EEHC-EETC-Cisplatin combination at $1 / 6 \mathrm{IC}_{50}$ concentration. Annexin V is a member of the family of phospholipid-binding protein on negatively charged cell membranes. Cell death caused by apoptosis or necrosis can be distinguished by staining propidium iodide (PI) through intercalation with DNA (Zhang et al., 1997). 
Table VI. The percentage of 4T1 cell mortality after treatment

\begin{tabular}{cccccc}
\hline & Control & $\begin{array}{c}\text { EEHC } \\
(1 \mu \mathrm{g} / \mathrm{mL})\end{array}$ & $\begin{array}{c}\text { EETC } \\
(6 \mathrm{mg} / \mathrm{mL})\end{array}$ & $\begin{array}{c}\text { Cisplatin } \\
(2.5 \mu \mathrm{M})\end{array}$ & $\begin{array}{c}\text { EEHC 1 ug/mL + } \\
\text { EETC 6 mg/mL }+ \\
\text { Cis 5.3 } \mu \mathrm{M}\end{array}$ \\
\hline Early apoptosis (\%) & 1.45 & 2.34 & 1.52 & 2.64 & 10.92 \\
Late Apoptosis (\%) & 1.63 & 0.62 & 2.13 & 2.53 & 1.24 \\
Necrosis (\%) & 0.86 & 0.65 & 0.98 & 0.87 & 1.62 \\
Total & 3.94 & 3.61 & 4.63 & 6.04 & 13.78 \\
\hline
\end{tabular}

After single and combination treatments (Table VI), the cell death of the control cell is at a rate of $3.94 \%$. Single treatments using EEHC, EETC, and cisplatin caused, respectively, $3.61 \%$, $4.63 \%$, and $6.04 \%$ of cell death, whereas their combination resulted in $13.78 \%$ of cell death. These results prove that compared to the single use of cisplatin, the combination treatment can increase cell death by $7.4 \%$. The extract can inhibit the phosphorylation of signal transducers and activate STAT, which is a prerequisite for the transcription process (Rabbi et al., 2008).

At the molecular level, c-Myc decrease transcription, mitochondrial biogenesis, the biosynthesis of RNA and proteins, anaplerosis, and glutaminolysis and increase gene inhibitors. Meanwhile, at the cellular level, they reduce cell proliferation, transformation metabolism, and the capacity of metastasis (Miller et al., 2012).

\section{CONCLUSION}

The optimum combination of the ethanolic extract of Hedyotis corymbosa L. (1/6 IC $\mathrm{I}_{50}$, $1 \mu \mathrm{g} / \mathrm{mL})$, the ethanolic extract of Tinospora crispa $\left(1 / 6 \mathrm{IC}_{50}, 6 \mu \mathrm{g} / \mathrm{mL}\right)$, and cisplatin $(1.68 \mathrm{mg} / \mathrm{mL})$ can enhance the cytotoxic effects of cisplatin against breast cancer cells, chiefly $4 \mathrm{~T} 1$. It has a synergistic effect with CI of 0.58 , induces S-phase cell cycle arrest in 4T1 cells, and increases the induction of apoptosis in these cells.

\section{ACKNOWLEDGMENT}

The authors are grateful to the Laboratory of Chemistry and Pharmacy at the University of Ma Chung for its invaluable support for this research.

\section{REFERENCES}

Damu, A.G., Kuo, P.C., Shi, L.S., Li, C.Y., Su, C.R., and Wu, T.S., 2009, Cytotoxic Berberina alkaloids from the stem of Tinosporacrispa, Planta Medica, 75: 1152-1156.

Miller.M.D., Shelia D. Thomas., Ashraful Islam. David Muench and KaraSedoris., 2012, c-Myc and cancer metabolism, Clinical Cancer Research, 18 (20): 5546-5553.

Florea, M.A., and Busselberg, D., 2011, Cisplatin as an anti-tumor drug: cellular mechanism of activity, drug resistance, and induced side effect. Cancer, 3: 1351-1371.

Foo, S.Y., and Nolan, G.P., 1999. NF-kappaB to the Rescue: reels, Apoptosis and Cellular Transformation. Trends in Genetics, 6: 229-235.

Foster, I., 2008, Cancer: A Cell Cycle Defect. Radiography, 14: 144-149.

Harborne, J.B., 1987, Phytochemical Methods: Analyzing the Modern Way Guidance Plant. ITB Bandung, Bandung.

Matthews, H., Jon Deakin, May Rajab, Maryam Idris-Usman, Niroshini J. Nirmalan, 2017, Investigating antimalarial drug interactions of emetine dihydrochloride hydrate using CalcuSyn-based interactivity calculations, PLoSONE, 12(3): e0173303.

IARC, 2012, Globocan 2012: Estimated Incidence of Cancer, Mortality and Prevalence Worldwide in 2012. Retrieved on August 2016.

Jamieson, E..R, and Lippard, S.J., 1999, Structure, recognition, and processing of cisplatin DNA adducts. Chemical Reviews, 99(9): 2467-2498. 
King, RJB, 2000, Cancer Biology, 2nd ed. Pearson Education Limited, London.

Kaur, P., Nagaraja, G.M., Zheng, H., Gizachew, D., Galukande, M., Krishnan, S., Asea, A. 2012, A mouse model for breast cancer triple negative tumor-initiating cells (TNBCTICs) Similar exhibits aggressive phenotype to the human disease. BMC Cancer, 12:120: 1-12.

Kemper, K., Goeje, P.L., de Peeper, D.S., Amerongen, R. van. Phenotype, 2014, Switching: tumor cell plasticity as a resistance mechanism and targets for therapy. Cancer Research, 74(21): 5937-5941.

Lin, W.P., Rao, H., Su Chia Sheng, KC, Shung, and Wu, T., 2002, Phenanthroindolizidine alkaloids and their cytotoxicity from the Leaves of Ficus septica. Heterocycles, 57(12): 24012408.

Milosavlievic, N., Duranton, C., Djerbi, N., Puech, P., Gounon, P., Lagadic Gossmann, D., Dimanche-Boitrel, M.T., rauch, C., Tauc, M., Counillon, L., Poet, M., 2010, Effects of Cisplatin Nongenomic: Acute Inhibition of Mechanosensitive Transporters and Channels Without actin Remodeling. Molecular and Cellular Pathobiology, 70(19): 7514-7522.

Rollando, 2018, Combination Ofhedyotis Corymbosa L. and Tinospora Crispa Ethanolic Extract Increase Cisplatin Cytotoxicity on T47d Breast Cancer Cells, Asian Journal of Pharmaceutical and Clinical Research, 11(7): 171-177.

Minami, M., Matsumoto, S., and Horiuchi, H., 2010, Cardiovascular Side-effects of Modern Cancer Therapy, Circulation Journal, 74(9): 1779-1786.

Rabbi, T., Anupam Bishayee, 2008, terpenoids and breast cancer chemoprevention (review). Breast Cancer Research and Treatment, 115: 223-239.

Reynolds, C.P., and Maurer, B.J., 2005, Evaluating response to antineoplastic drug combinations in tissue culture models, Methods in Moleculer Medicine, 110: 173-183.

Ross, J.S., Linette, G.P., Stec, J., Ross, M.S., Anwar, S., dan Boguniewics, A., 2003, DNA ploidy and cell cycle analysis in breast cancer, American Journal of Clinical Pathology, 120: 572584.

MOH, 1985, Indonesian Medicinal Plants, I. Ministry of Health of the Republic of Indonesia, Jakarta.

Aprianto, Y., Asri, M., Fadliyah,H., Murwanti, R., Meiyanto, E., 2017, antigenotoxic activity of pearl grass (Hedyotis corymbosa L.) Ethanolic extract on cyclophosphamide-induced mice, Indonesian Journal of Cancer Chemoprevention, 8(3): 127-136.

Valeriote, F., Grieshaber, CK, Media, J., Pietraszkewicz, H., Hoffmann, J., Pan, M., McLaughlin S., 2002, Discovery and Development of Anticancer Agents from Plants. Journal of Experimental Therapeutics and Oncology, 2(4): 228-236.

Waqas, A., Male, I., Bukhari., N., S., 2016, Tinospora crispa (1.) Hook. f. \& Thomson: a review of its ethnobotanical, phytochemical, and pharmacological aspects, Front Pharmacol, 7(59): 119.

WHO, 2013, Cancer. Retrieved on August 2016.

Zhang, G., Gurtu, V., Cain, S.R., and Yan, G., 1997, Early detection of apoptosis using a fluorescent conjugate of annexin V, BioTechnique, 23(3): 525-531.

Zhao, L., Wientjes, MG, and Au, JL, 2005. Evaluation of combination chemotherapy: integration of nonlinear regression, curve shift, isobologram, and combination index analyses, Clicinal Cancer Research, 10(3): 7994-8004. 
